\title{
Regionale diversiteit, ecologie en paleo-ecologie van aquatische invertebratengemeenschappen in Oost-Afrikaanse meren
}

\author{
Bob Rumes \\ Promotor: Dirk Verschuren \\ Vakgroep Biologie, Universiteit Gent
}

Openbare verdediging: 11 maart 2010

Gezien de wereldwijde toename van het gebruik van land door de mens is het een belangrijke uitdaging voor aquatische ecologen om te bepalen in welke mate deze menselijke activiteiten een invloed hebben op de structuur en de functie van aquatische ecosystemen. Daarenboven wordt verwacht dat klimaatveranderingen en klimaatschommelingen extra druk zullen zetten op zowel de beschikbaarheid van als de toegang tot (zoet) water in Afrika (Boko et al., 2007). Een grondige kennis over de respons van zoetwaterecosystemen op vroegere variaties in klimaat en menselijke invloed is essentieel om een beter inzicht te verwerven in de veerkracht van deze ecosystemen. Het laat toe een inschatting te maken van hun veerkracht ten opzichte van de voorspelde klimaatverandering en de verwachte toename van intensief landgebruik. Dit is op zijn beurt noodzakelijk voor het opstellen van een beheersstrategie die het behoud van de functies en de diensten van het ecosysteem op lange termijn weet te handhaven.

Met zijn doctoraatsstudie: "Regionale diversiteit, ecologie en paleo-ecologie van aquatische invertebratengemeenschappen in Oost-Afrikaanse meren" wil Bob Rumes de respons en het herstelvermogen van Oost-Afrikaanse meren op veranderingen in het milieu nagaan. De nadruk werd gelegd op de gevoeligheid van lokale aquatische gemeenschappen voor abiotische veranderingen in hun omgeving alsook op de snelheid en de wijze van het herstel na een periode van verstoring. In dit onderzoek werden de natuurlijke klimaatsgedreven veranderingen in het aquatische milieu (variatie in habitat gerelateerd aan veranderingen in meerniveau en saliniteit) onderzocht evenals de veranderingen door menselijke verstoring van het meer en het omringende terrestrisch ecosysteem.

In een eerste onderzoeksluik werden de hedendaagse ongewervelde zoetwatergemeenschappen uit West-Oeganda en Zuid-Kenia bestudeerd. Op deze manier werd nagegaan welke omgevingsparameters de soortensamenstelling bepaalt. De verspreiding van Cladocera (watervlooien; Crustacea: Branchiopoda), Ostracoda (mosselkreeftjes; Crustacea: Ostracoda), aquatische insecten (Arthropoda: Insecta), mosmijten (Acari: Oribatida), mosdiertjes (Bryozoa: Plumatellidae) en testate amoeben (Protista: Rhizopoda) werd het sterkst beïnvloed door het beschikbare littorale habitat (oa. waterplanten en oevervegetatie), saliniteit, zuurtegraad $(\mathrm{pH})$ en aquatische productiviteit en men kan deze groepen gebruiken als indicatoren voor de waterkwaliteit en de gezondheid van het ecosysteem in West-Oegandese kratermeren. Een analyse van de relatie tussen de al- 
gemene diversiteit van de bestudeerde huidige ongewervelde fauna in de meren en het landgebruik in hun meerbekkens, duidde op een negatief verband tussen landbouwactiviteiten op de - overwegend steile - kraterwanden van het meerbekken en aquatische biodiversiteit.

Om op accurate wijze vroegere aquatische ecosystemen te reconstrueren is het noodzakelijk het verband tussen de levende fauna en de fossiele resten te begrijpen (Frey, 1986). Van 6r West-Oegandese kratermeren werd de samenstelling van de assemblages aan aquatische ongewervelden uit oppervlaktesedimenten (de recent gedeponeerde resten) vergeleken met de samenstelling van de levende fauna. Dit om te bepalen hoe goed individuele taxa bewaard bleven en in welke mate de samenstelling van de resten in de oppervlaktesedimenten uit het midden van het meer de hedendaagse (levende) fauna weerspiegelde. Hieruit bleek dat dezelfde omgevingsparameters zowel de levende gemeenschappen als het fossiele assemblage beïnvloeden, naast het feit dat de samenstelling van deze laatste groep ook sterk afhangt van de grootte en de diepte van het meer. Dit laatste illustreert het belang van de vorm van het meerbekken op de ruimtelijke integratie van de resten voor ze bedolven worden.

De methodologie die werd ontwikkeld in het eerste deel van deze studie werd vervolgens toegepast op het sedimentarchief van twee zoetwater kratermeren in West-Oeganda (Wandakara en Katinda). Het fossiele archief van dansmuglarven (Diptera: Chironomidae), watervlooien, mosselkreeftjes en andere aquatische ongewervelden werd gebruikt om, over de periode van de laatste 4000 jaar, de langetermijn-respons van aquatische gemeenschappen op lokale veranderingen in het milieu te reconstrueren. Onze analyses geven aan dat de aquatische biota in West-Oegandese meren onderhevig zijn geweest aan sterke natuurlijke schommelingen in omgevingsparameters (oa. uitgesproken droogteperiodes). Vanaf ffi2150 (in Katinda) en ffigoo (in Wandakara) jaar geleden hebben menselijke invloeden de samenstelling van de aquatische ongewervelde fauna sterk gewijzigd. De aquatische ongewervelde fauna heeft zich slechts deels kunnen herstellen toen de mens de streek voor meer dan 150 jaar verliet hetgeen erop wijst dat het herstel van het ecosysteem een relatief traag proces is. In beide meren waren de effecten op het aquatisch leven ten gevolge van de natuurlijke veranderingen in het milieu ondergeschikt aan de veranderingen te wijten aan veranderingen in landgebruik door de mens. Gecombineerde maatregelen ten bevordering van duurzaam landbeheer en voor het behoud van de aquatische biodiversiteit zullen nodig zijn als garantie voor het langdurig behoud van de ecosysteemfuncties en -diensten in West-Oegandese kratermeren, vooral met het oog op een explosieve populatiegroei en de natuurlijke en de door de mens veroorzaakte klimaatverandering.

Het potentieel van deze paleo-ecologische methodologie werd verder geilllustreerd aan de hand van reconstructies in Lake Emakat (Empakaai Krater, Noord-Tanzania) en het Yoa meer (Ounianga regio, Noordoost-Tsjaad), waar de respons van de aquatische ongewervelden op veranderingen in het milieu werd gebruikt om respectievelijk de periode van de post-glaciale opwarming en de uitdroging van de Sahara in het Middenen Laat-Holoceen te documenteren. In beide gevallen werd bewezen dat een snelle bi- 
ologische doorlichting van de fossiele groepen van relatief grote ( $>150 \mu \mathrm{m}$ ) resten van verschillende aquatische ongewervelden erg waardevol is om vroegere veranderingen in meerniveau, nutriëntenrijkdom en zoutgehalte te reconstrueren. Daarenboven is het ook een belangrijk hulpmiddel bij de interpretatie van reconstructies op basis van andere proxies.

\section{Referenties}

Boko, M., I. Niang, A. Nyong, C. Vogel, A. Githeko, M. Medany, B. Osman-Elasha, R. Tabo \& P. Yanda (2007). 208 Africa. In: Change, Parry M.L., O.F. Canziani, J.P. Palutikof, P.J. van der Linden \& C.E. Hanson (eds.), Climate 209 Change 2007: Impacts, Adaptation and Vulnerability. Contribution of Working Group II to the Fourth Assessment 210. Report of the Intergovernmental Panel on Climate, Cambridge University Press, Cambridge, UK, 967 pp. 211.

Frey, D.G. (1986). Cladocera analysis. In: Handbook of Holocene Palaeoecology \& 212 Palaeohydrology, Berglund, B. E. (ed.), John Wiley \& Sons, Chichester, New York, USA, 869 p.

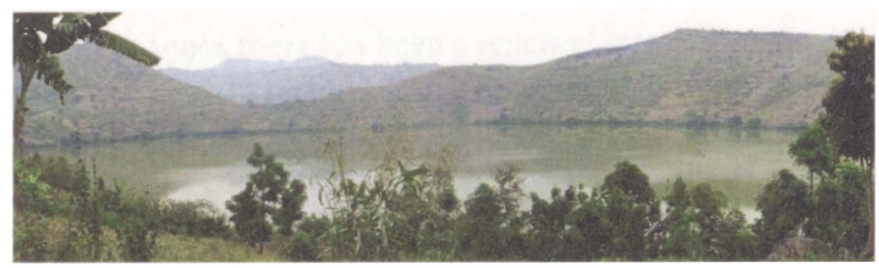

Eén van de bestudeerde zoetwatermeren in West-Oeganda (Katinda).

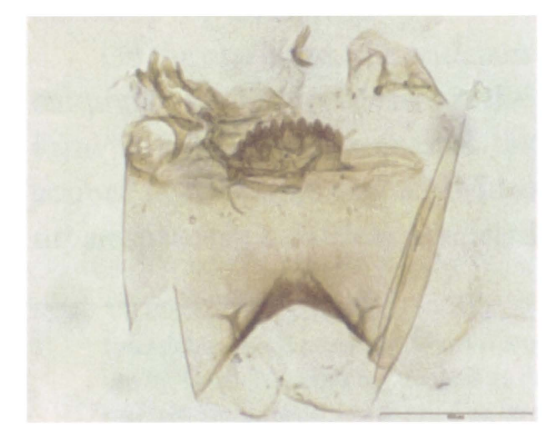

Cladotanytarsus pseudomancus (Chironomidae: Dansmuggen) een indicatorsoort voor grofkorrelige, zanderige substraten, in Katinda geassocieerd met toegenomen (anthropogene) erosie. 